\title{
In Vivo Experimental Endovascular Uses of Cyanoacrylate in Non-Modified Arteries: A Systematic Review
}

\author{
Kévin Guillen ${ }^{1,2} \mathbb{D}$, Pierre-Olivier Comby ${ }^{2,3}$, Olivier Chevallier ${ }^{1,2} \mathbb{D}$, Anne-Virginie Salsac 4 \\ and Romaric Loffroy $1,2, * \mathbb{D}$
}

1 Department of Vascular and Interventional Radiology, Image-Guided Therapy Center, François-Mitterrand University Hospital, 14 Rue Paul Gaffarel, BP 77908, 21079 Dijon, France; kevin.guillen@chu-dijon.fr (K.G.); olivier.chevallier@chu-dijon.fr (O.C.)

2 Imaging and Artificial Vision (ImViA) Laboratory-EA 7535, University of Bourgogne/Franche-Comté, 9 Avenue Alain Savary, BP 47870, 21078 Dijon, France; pierre-olivier.comby@chu-dijon.fr

3 Department of Neuroradiology and Emergency Radiology, François-Mitterrand University Hospital, 14 Rue Paul Gaffarel, BP 77908, 21079 Dijon, France

4 Biomechanics and Bioengineering Laboratory, UMR CNRS 7338, Université de Technologie de Compiègne, 60203 Compiègne, France; anne-virginie.salsac@utc.fr

* Correspondence: romaric.loffroy@chu-dijon.fr; Tel.: +33-380-293-677

check for updates

Citation: Guillen, K.; Comby, P.-O.; Chevallier, O.; Salsac, A.-V.; Loffroy, R. In Vivo Experimental Endovascular Uses of Cyanoacrylate in Non-Modified Arteries: A Systematic Review. Biomedicines 2021, 9, 1282. https:// doi.org/10.3390/biomedicines9091282

Academic Editor: Régis Guieu

Received: 22 August 2021

Accepted: 15 September 2021

Published: 21 September 2021

Publisher's Note: MDPI stays neutral with regard to jurisdictional claims in published maps and institutional affiliations.

Copyright: (c) 2021 by the authors. Licensee MDPI, Basel, Switzerland. This article is an open access article distributed under the terms and conditions of the Creative Commons Attribution (CC BY) license (https:// creativecommons.org/licenses/by/ $4.0 /)$.

\begin{abstract}
Cyanoacrylates were first used for medical purposes during World War II to close skin wounds. Over time, medical applications were developed, specifically in the vascular field. Uses now range from extravascular instillation in vascular grafting to intravascular injection for embolization. These applications were made possible by the conduct of numerous preclinical studies involving a variety of tests and outcome measures, including angiographic and histological criteria. Cyanoacrylates were first harshly criticized by vascular surgeons, chiefly due to their fast and irreversible polymerization. Over the past five years, however, cyanoacrylates have earned an established place in endovascular interventional radiology. Given the irreversible effects of cyanoacrylates, studies in animal models are ethically acceptable only if supported by reliable preliminary data. Many animal studies of cyanoacrylates involved the experimental creation of aneurysms or arteriovenous fistulas, whose treatment by endovascular embolization was then assessed. In clinical practice, however, injection into non-modified arteries may be desirable, for instance, to deprive a tumor of its vascular supply. To help investigators in this field select the animal models and procedures that are most appropriate for their objectives, we have reviewed all published in vivo animal studies that involved the injection of cyanoacrylates into non-modified arteries to discuss their main characteristics and endpoints.
\end{abstract}

Keywords: cyanoacrylate; NBCA; endovascular; animal studies; swine; rabbit; rat; dog; artery; artery model

\section{Introduction}

N-butyl cyanoacrylate (NBCA) is generating considerable interest among interventional radiologists given its good efficacy and biological tolerance when used for endovascular embolization. Practices regarding the clinical uses of NBCAs vary across countries. For instance, Glubran ${ }^{\circledR} 2$ (GEM, Viareggio, Italy) has obtained the European Conformity (EC) mark, whereas Trufill ${ }^{\circledR}$ (Cordis, Miami Lakes, FL, USA) has been approved by the Food and Drug Administration in the US but is not available elsewhere. Histoacryl ${ }^{\circledR}$ is also an NBCA and is available in the USA and Japan but is normally "off-label" in Europe for endovascular purposes in humans, although it has been used for a long time. Bucrylate ${ }^{\circledR}$, or isobutyl 2-cyanoacrylate (IBCA), was used in early studies before it was demonstrated that NBCA had a better safety profile and greater tensile strength. General agreement exists about the usefulness, when performing intra-arterial injections of cyanoacrylates, 
of adding a radio-opaque agent that delays polymerization and provides angiographic guidance for controlling polymerization kinetics [1].

Preclinical studies are one of the available means of increasing our knowledge of NBCAs and identifying their best clinical applications. The adequate conceptualization of relevant experimental models is needed to apply an evidence-based methodology capable of producing a high level of basic science evidence. Most studies of the in vivo uses of endovascular NBCA focused on aneurysms or arteriovenous malformations (AVMs) [2]. Different models have been developed to mimic different clinical situations. Thus, rete mirabile embolization through the ascending pharyngeal artery in swine serves as a model for the treatment of AVMs [3]. Aneurysms, including aortic aneurysms, have been created in rabbits and swine and in arteriovenous fistulas in dogs [4-8]. However, to our knowledge, no review of cyanoacrylate injection into non-modified arteries in animal models is available. Embolization by injection into non-modified arteries is sometimes needed in clinical practice, for instance, to deprive a tumor of its blood supply before surgical excision, or to stop arterial bleeding via the transfemoral approach [9]. Moreover, knowledge of the behavior of cyanoacrylates in non-modified arteries may prove valuable.

When interest in cyanoacrylates-which have been available for many years-was recently rekindled, studies identified several issues requiring further investigation [10]. The objective of this systematic review of the experimental studies of cyanoacrylates injected into non-modified arteries in animal models was to help investigators choose the in vivo model and embolization site most likely to provide the answer to their research questions based on all the data published to date.

\section{Materials and Methods}

\subsection{Literature Search Strategy}

We performed an exhaustive computerized search of the Medline/PubMed and Web of Science databases, which complement each other. The search period was 1950 to 2020. We used the following keywords in all possible paired combinations separated by the Boolean operator AND: "cyanoacrylate", "lipiodol", "endovascular", "in vivo", "experimental", "mice", "sheep", "dog", "rabbit", and "primate". We then manually checked the reference lists of the articles that were retrieved.

Study inclusion criteria were as follows: English or French language, original research (conferences, letters, abstracts, and editorials were not included), publication after peer review, use of cyanoacrylate for endovascular arterial embolization, and no experimental change to the embolized artery (i.e., no aneurysms or AVMs were created). The second author (P.O.C.) independently assessed the eligibility of the studies and the reproducibility of the computerized search. Disagreements were resolved by having P.O.C. and R.L. review the article together to reach a consensus.

\subsection{Outcomes}

To our knowledge, no standardized reviewing protocol exists for experimental animal studies. We drew from the Preferred Reporting Items for Systematic Reviews and MetaAnalyses (PRISMA) extension for scoping reviews (PRISMA-ScR), although it was designed for clinical reviews [11,12]. The data from the selected studies were entered into an electronic spreadsheet listing the following characteristics: publication (first author's name and country, year, URL); primary study objective; species, number of animals used, and number of models; clinical situations the model was designed to mimic; chemical and commercial names of the cyanoacrylate used; any other compounds used, with the ratio relative to cyanoacrylate; name of the embolized vessels and how they were approached; amount injected; size of the introducer and microcatheters; guiding modality; detailed outcomes (e.g., histological and angiographic findings); and follow-up duration and data. Our findings are reported as a narrative review, with references but without comparisons across studies. 


\section{Results}

\subsection{Included Studies}

Our exhaustive search strategy retrieved 428 articles. Figure 1 is the flowchart. After the initial screening of the titles and abstracts, we excluded 141 papers, most of which dealt with the NBCA embolization of experimentally produced AVMs or aneurysms. When the same study involved the endovascular treatment of both prepared and non-modified arteries, only the data regarding the non-modified arteries were considered. The crossmatching of reference lists and review articles identified five additional studies, leading to a total of 64 studies. After the examination of the full texts, we found that 20 articles did not meet our selection criteria; for example, eight of them studied intravenous cyanoacrylate.
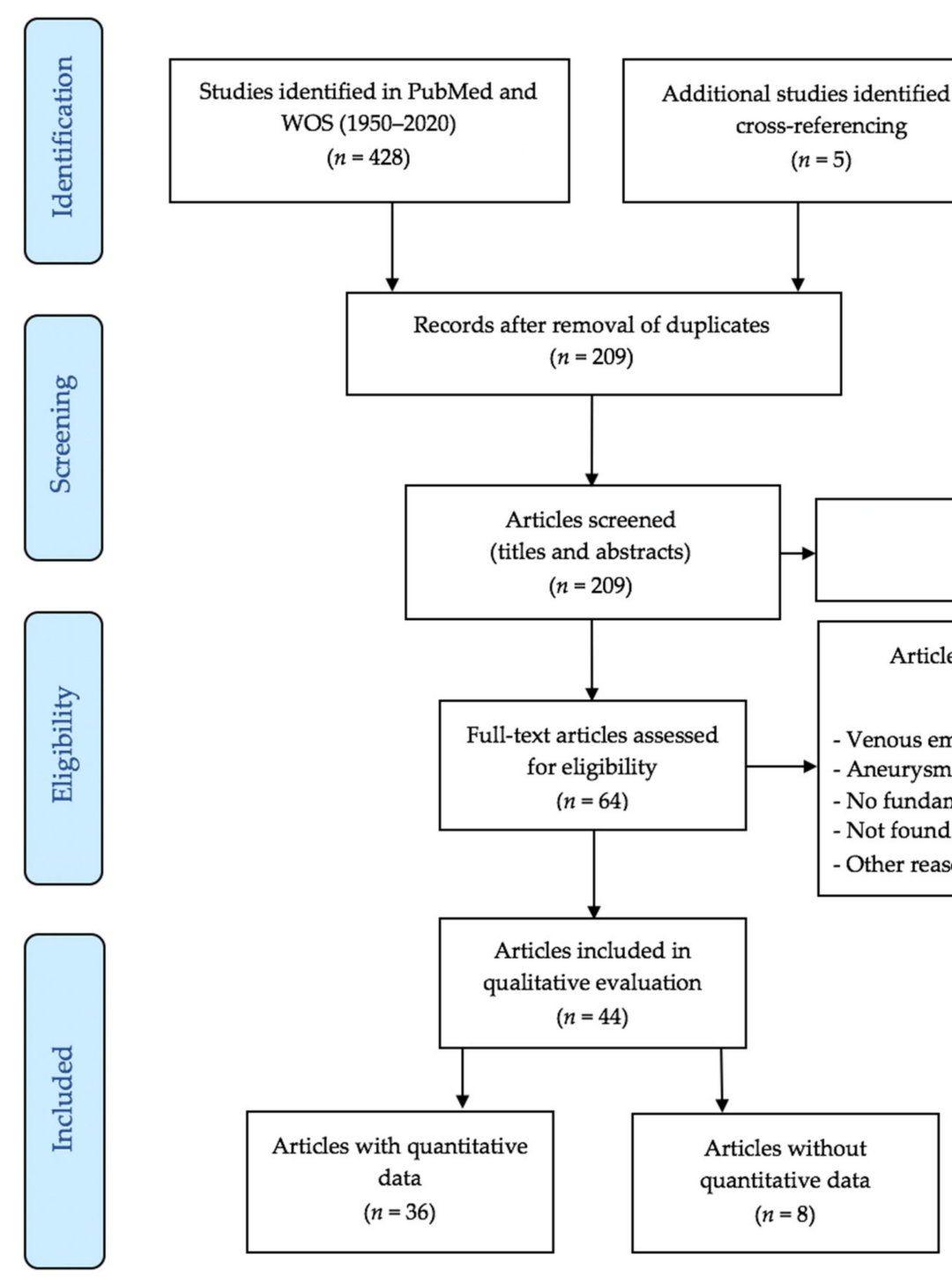

Figure 1. Flow chart. WOS, Web of Science; AVM, arteriovenous malformation.

This left 44 studies for our qualitative analysis of the model characteristics. Their distribution by year of publication is shown in Figure 2. Of the 44 studies, 16 were completed in swine, 17 in dogs, 7 in rabbits, 2 in primates, and 2 in other species. The information needed for a quantitative evaluation of the embolization mixture and procedure characteristics was supplied by 36 of the 44 articles. 


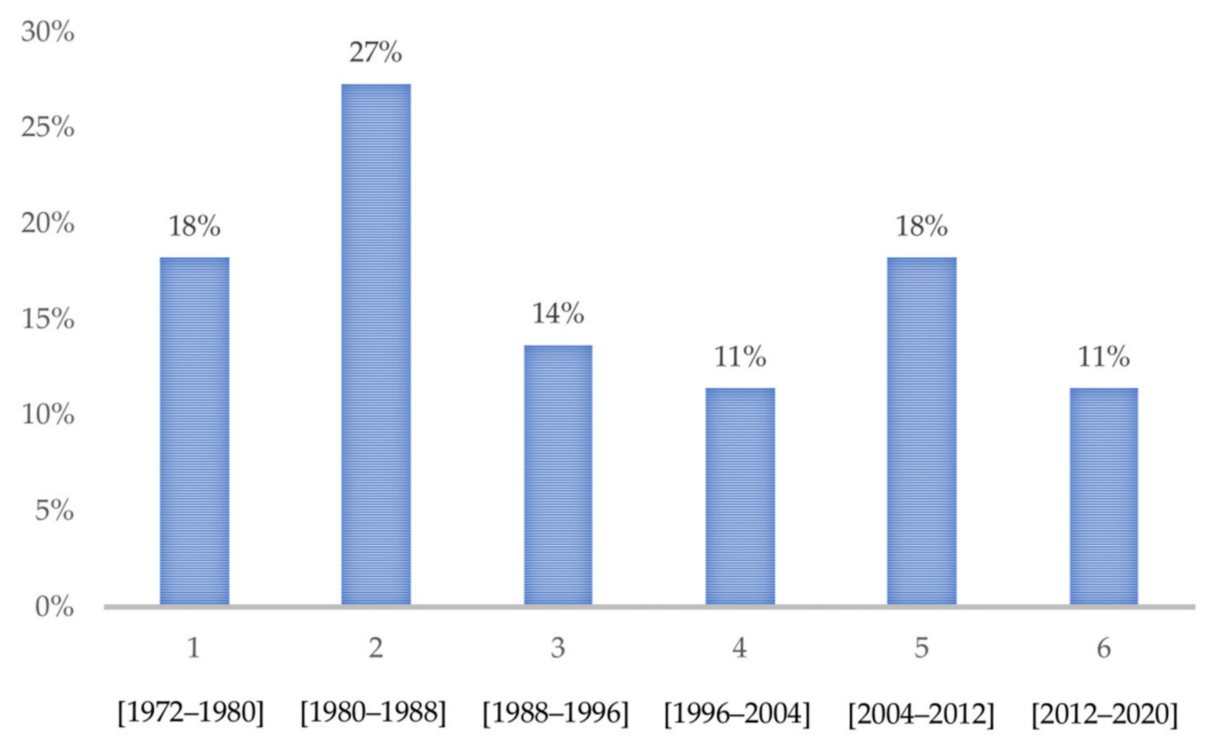

Figure 2. Percentage of studies identified during consecutive 8-year periods from 1972 to 2020.

\subsection{General Characteristics}

Most of the publications were by North American authors (USA and Canada), although Japan and China also made substantive contributions (Figure 3). The total number of animals used was 1042, with 454 rats in 4 studies. The main objectives fell into two groups: the evaluation of polymerization kinetics or other characteristics (33 studies, including 11 with Histoacryl ${ }^{\circledR}$ (B/Braun, Tuttlingen, Germany), 8 with Bucrylate ${ }^{\circledR}$, and 1 with Glubran ${ }^{\circledR} 2$ ), and the development of models that replicated clinical situations, such as ischemia (six studies, half of which used Histoacryl ${ }^{\circledR}$ and none Glubran ${ }^{\circledR} 2$ ). In five other studies, cyanoacrylates were used to document the characteristics of a new tool (e.g., a balloon-microcatheter) or the effects of embolization on the neighboring tissues. Overall, the mean model follow-up was 31 days, the median was 3 days, and the range was 0 to 180 days (with the longest follow-up in mongrel dogs); of the 44 studies, 15 involved euthanasia on the same day as the endovascular intervention.

\section{Geographical distribution of publications}
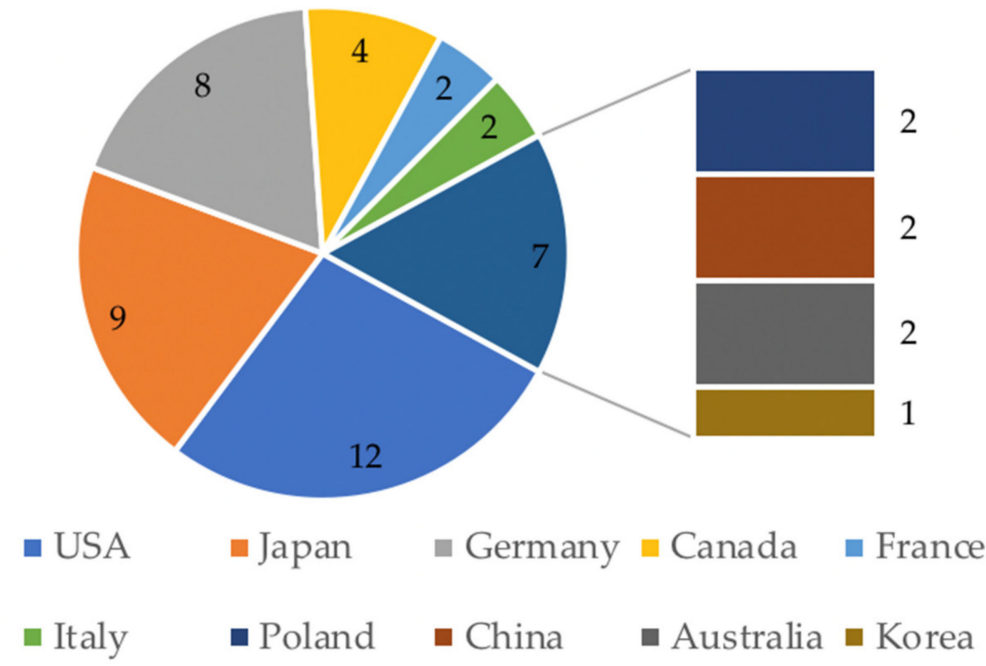

Figure 3. Geographical distribution of the first authors of the included studies (graphic indicates the number of publications of each country). 


\subsection{Procedures}

Most of the procedures were completed under fluoroscopic guidance $(41 / 44,93 \%)$ via the transfemoral approach. In the remaining three studies, the microcatheter was inserted directly into the target artery.

Tables 1-3 report the main quantitative data in studies of dogs, swine, and rabbits, respectively. Three articles, on primate and rat models, were not considered for the quantitative evaluation, which thus relied on 33 articles [8,13-45].

The ranges of end-tip external diameters for dog, swine, and rabbit models were 1.0-4.2 French (Fr), 2.0-4.1 Fr, and 1.5-3.6 Fr, respectively. The cyanoacrylate absolute concentrations in the injected substance ranged from $10 \%$ to $100 \%$. Figure 4 is a histogram showing the frequencies of arterial sites used for embolization. In 19 (57\%) of the 33 studies, the renal artery was embolized. When radio-opaque agents were added to allow real-time control of the embolization while also adjusting the polymerization time, Lipiodol was chosen in $47 \%$ and iophendylate in $22 \%$ of the cases. Importantly, iophendylate was used in the earliest studies, and Lipiodol was used in the more recent work. Tantalum powder was the third most commonly used contrast agent and had no effect on cyanoacrylate polymerization characteristics.

Percentages of studies that used each embolization site; the denominator was the total number of studies with quantitative data $(n=36)$

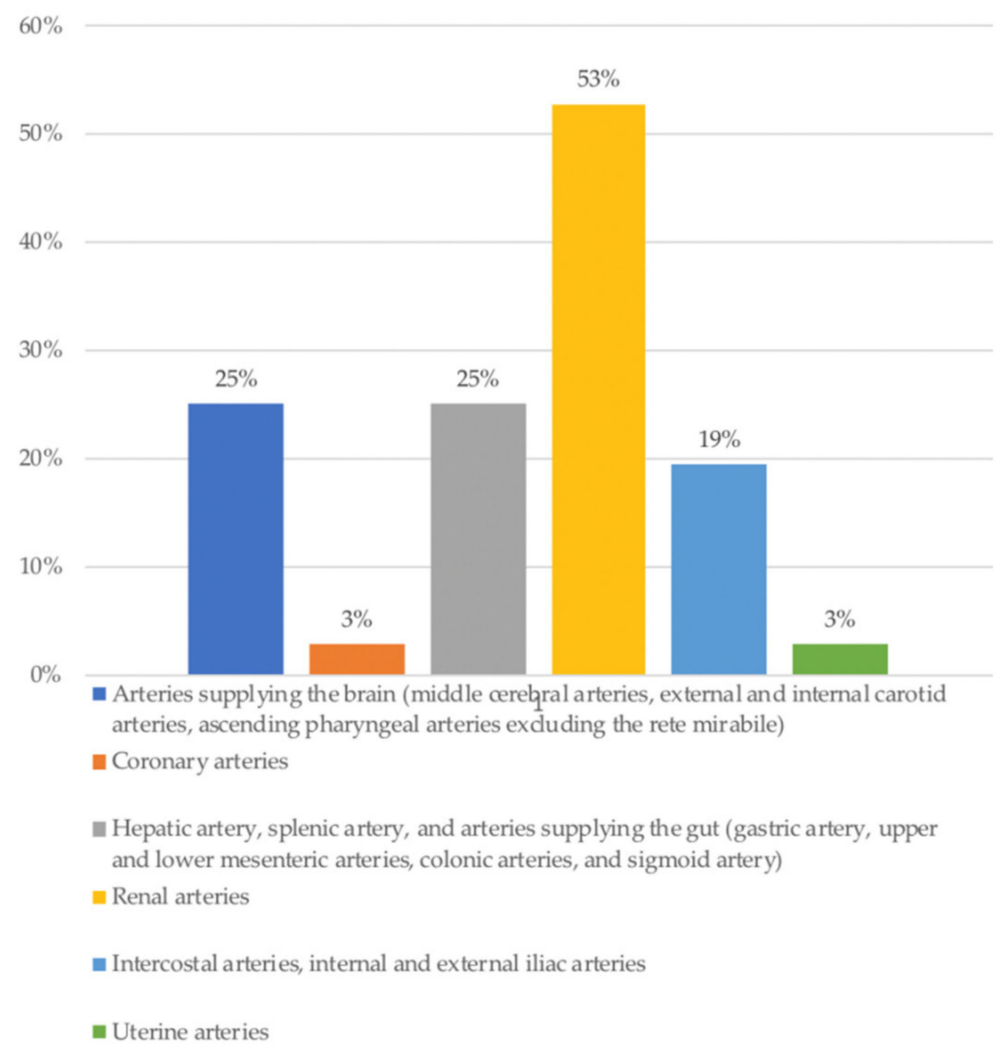

Figure 4. Percentages of studies that used each embolization site; the denominator was the total number of studies with quantitative data $(n=36)$. 
Table 1. Quantitative data from studies of dog models.

\begin{tabular}{|c|c|c|c|c|c|c|c|c|c|}
\hline $\begin{array}{l}\text { Cyanoacrylate } \\
\text { Glue Used }\end{array}$ & $\begin{array}{l}\text { Radiopaque } \\
\text { Agent }\end{array}$ & $\begin{array}{c}\text { Other } \\
\text { Components }\end{array}$ & $\begin{array}{c}\text { Absolute } \\
\text { Cyanoacrylate } \\
\text { Concentration (\%) }\end{array}$ & $\underset{(\mathrm{mL})}{\operatorname{Amount}}$ & Embolization Site & $\begin{array}{c}\text { Microcatheter } \\
\text { Distal Tip-External } \\
\text { Diameter (French) }\end{array}$ & $\begin{array}{l}\text { Introducer Size } \\
\quad \text { (French) }\end{array}$ & Authors & $\begin{array}{c}\text { Publication } \\
\text { Year }\end{array}$ \\
\hline $\begin{array}{l}\text { Commercial } \\
\text { cyanoacrylate }\end{array}$ & None & None & 0.96 & 0.05 & $\begin{array}{l}\text { Superior cerebral artery } \\
\text { and anterior } \\
\text { communicating artery }\end{array}$ & DP & DP & Guo et al. [13] & 1995 \\
\hline Histoacryl ${ }^{\circledR}$ (NBCA) & Ethiodized oil & Tantalum powder & $0.17-0.33$ & $0.5-1$ & Coronary artery & NR & 7.0 & Matos et al. [14] & 2005 \\
\hline Histoacryl ${ }^{\circledR}$ (NBCA) & Lipiodol & None & 0.25 & $0.1-0.3$ & $\begin{array}{l}\text { Superior mesenteric artery } \\
\text { Left gastric artery, }\end{array}$ & 3.0 & 5.0 & Jae et al. [15] & 2008 \\
\hline Bucrylate $^{\circledR}$ (IBCA) & $\begin{array}{l}\text { Tantalum powder } \\
\text { alone }\end{array}$ & None & 1 & $0.3-0.5$ & $\begin{array}{l}\text { gastroduodenal artery, } \\
\text { inferior } \\
\text { pancreatico-duodenal } \\
\text { artery, and branches of the } \\
\text { superior mesenteric artery }\end{array}$ & 3.0 & 6.7 & Dotter et al. [16] & 1975 \\
\hline Histoacryl ${ }^{\circledR}$ (NBCA) & Lipiodol & None & $0.1-0.5$ & 0.43 & Renal artery & 2.0 & 8.0 & Takasawa et al. [17] & 2012 \\
\hline Bucrylate $^{\circledR}$ (IBCA) & Iophendylate oil & None & 0.5 & NR & Renal artery & DP & DP & Cromwell et al. [18] & 1986 \\
\hline Bucrylate $^{\circledR}$ (IBCA) & Iophendylate oil & $\begin{array}{l}\text { Tantalum powder, } \\
\text { Glacial acetic acid }\end{array}$ & 0.75 & NR & $\begin{array}{l}\text { Renal artery and polar } \\
\text { arteries }\end{array}$ & $3.6-4.2$ & 7.0 & Spiegel et al. [19] & 1986 \\
\hline Bucrylate $^{\circledR}$ (IBCA) & $\begin{array}{l}\text { Tantalum powder } \\
\text { alone }\end{array}$ & $\begin{array}{l}\text { With or without } \\
\text { nitrocellulose }\end{array}$ & $0.96-1$ & $4-5.4$ & Renal artery & 3.0 & 5.0 & Sadato et al. [20] & 2000 \\
\hline Histoacryl ${ }^{\circledR}$ (NBCA) & $\begin{array}{l}\text { Lipiodol, } \\
\text { Urogranoic acid }\end{array}$ & None & $0.33-0.7$ & $0.5-2$ & $\begin{array}{l}\text { Renal artery and polar } \\
\text { arteries }\end{array}$ & 3.0 & DI & Szmigielski et al. [21] & 1981 \\
\hline Bucrylate $^{\circledR}$ (IBCA) & None & None & 1 & 0.15 & $\begin{array}{c}\text { Left renal artery } \\
\text { Branch of renal artery, }\end{array}$ & $1.5-2.6$ & NR & Zanetti et al. [8] & 1972 \\
\hline Bucrylate $^{\circledR}$ (IBCA) & Iophendylate oil & Tantalum powder & 0.75 & NR & $\begin{array}{l}\text { branch of external carotid } \\
\text { artery, and vertebral artery }\end{array}$ & $3.6-4.2$ & 7.0 & Debrun et al. [23] & 1982 \\
\hline Bucrylate $^{\circledR}$ (IBCA) & Iophendylate oil & None & 0.5 & NR & Renal and visceral arteries & 1.0 & 6.5 & Khangure et al. [24] & 1981 \\
\hline Bucrylate $^{\circledR}$ (IBCA) & Iophendylate oil & Tantalum powder & 0.75 & 0.13 & $\begin{array}{l}\text { Renal artery, splenic artery, } \\
\text { and anterior spinal artery } \\
\text { via the vertebral artery }\end{array}$ & 3.0 & $4.1-5.0$ & ApSimon et al. [25] & 1984 \\
\hline Histoacryl ${ }^{\circledR}$ (NBCA) & $\begin{array}{l}\text { Iophendylate oil, } \\
\text { Lipiodol }\end{array}$ & None & $0.2-0.5$ & NR & $\begin{array}{l}\text { Renal artery, intercostal } \\
\text { and lumbar arteries, } \\
\text { vertebral arteries, and } \\
\text { superior mesenteric artery }\end{array}$ & NR & 5.0 & Stoesslein et al. [26] & 1982 \\
\hline
\end{tabular}

\footnotetext{
NR, not reported; DP, direct puncture of the target artery; DI, direct insertion of the microcatheter without using an introducer; IBCA, iso-butyl cyanoacrylate; NBCA, N-butyl-cyanoacrylate.
} 
Table 2. Quantitative data from studies of swine models.

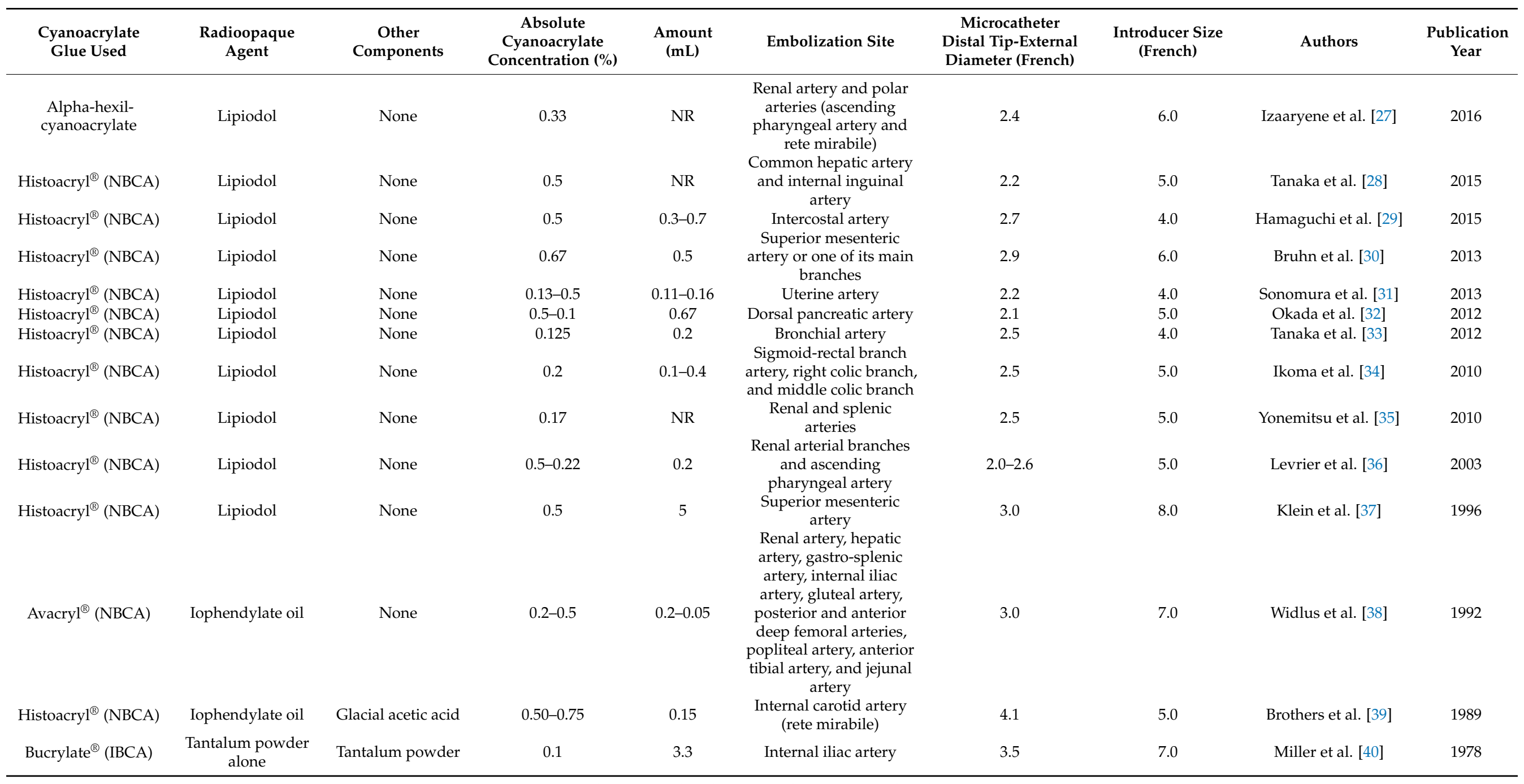

NR, not reported; IBCA, iso-butyl cyanoacrylate; NBCA, N-butyl-cyanoacrylate. 
Table 3. Quantitative data from studies of rabbit models.

\begin{tabular}{|c|c|c|c|c|c|c|c|c|c|}
\hline Cyanoacrylate Glue Used & $\begin{array}{l}\text { Radiopaque } \\
\text { Agent }\end{array}$ & $\begin{array}{c}\text { Other } \\
\text { Components }\end{array}$ & $\begin{array}{c}\text { Absolute } \\
\text { Cyanoacrylate } \\
\text { Concentration (\%) }\end{array}$ & $\underset{(\mathrm{mL})}{\operatorname{Amount}}$ & Embolization Site & $\begin{array}{c}\text { Microcatheter } \\
\text { Distal Tip-External } \\
\text { Diameter (French) }\end{array}$ & $\begin{array}{l}\text { Introducer Size } \\
\text { (French) }\end{array}$ & Authors & $\begin{array}{c}\text { Publication } \\
\text { Year }\end{array}$ \\
\hline Histoacryl ${ }^{\circledR}$ (NBCA) & Lipiodol & None & 0.5 & $0.1-0.2$ & Femoral artery & $\mathrm{DP}$ & $\mathrm{DP}$ & Wang et al. [41] & 2006 \\
\hline Histoacryl ${ }^{\circledR}$ (NBCA) & Iobenzene ester & None & 0.5 & $0.2-0.3$ & Right carotid artery & $2.0-2.7$ & DI & Shi et al. [42] & 2002 \\
\hline Histoacryl ${ }^{\circledR}$ (NBCA) & Lipiodol & $\begin{array}{l}\text { Glacial acetic } \\
\text { acid }\end{array}$ & $0.2-0.5$ & NR & $\begin{array}{l}\text { Subclavian and } \\
\text { femoral arteries }\end{array}$ & $1.8-2.7$ & 4.0 & Gounis et al. [43] & 2002 \\
\hline $\begin{array}{c}\text { Histoacryl }{ }^{\circledR}(\mathrm{NBCA}) \\
\text { Isostearyl-2-cyanoacrylate }\end{array}$ & Ethiodol & Ethiodol & $0.5-0.2$ & 0.2 & Renal artery & 2.7 & DI & Sadato et al. [20] & 2000 \\
\hline $\begin{array}{l}\text { (derived from IBCA), } \\
\text { Histoacry }{ }^{\circledR} \text { (NBCA) }\end{array}$ & Lipiodol & None & 0.5 & 0.5 & Renal artery & 1.5 & NR & Oowaki et al. [22] & 1999 \\
\hline Bucrylate $^{\circledR}$ (IBCA) & $\begin{array}{l}\text { Tantalum } \\
\text { powder alone }\end{array}$ & $\begin{array}{l}\text { With or without } \\
\text { nitrocellulose }\end{array}$ & $0.96-0.99$ & $0.4-0.8$ & Renal artery & 3.0 & DI & Salomonowitz et al. [44] & 1983 \\
\hline Histoacryl ${ }^{\circledR}$ (NBCA) & $\begin{array}{l}\text { Tantalum } \\
\text { powder alone }\end{array}$ & None & $0.11-0.25$ & NR & Renal artery & $3.0-3.6$ & NR & Günther et al. [45] & 1978 \\
\hline
\end{tabular}

NR, not reported; DP, direct puncture of the target artery; DI, direct insertion of the microcatheter without using an introducer; IBCA, iso-butyl cyanoacrylate; NBCA, N-butyl-cyanoacrylate. 


\section{Discussion}

This review aimed to identify all of the studies that involved cyanoacrylate injection into non-modified arteries of animal models and were published between the early 1970s and now. We did not consider studies of aneurysm embolization as the methods used to produce aneurysms are associated with multiple sources of confounding. More specifically, the need to infuse a heparin sulfate solution and the induced local inflammation of the artery influence the reproducibility of aneurysm models [46]. Furthermore, although successful in vivo animal experiments do not necessarily predict clinical efficacy, they are of interest for developing embolic agents given the physicochemical similarities between experimental animals and humans $[17,47]$.

Animal experimentation has a number of drawbacks. First, sophisticated and costly tools that are appropriate for the species that is used are needed. Moreover, all in vivo imaging studies and interventions require controlled analgesia and monitoring in an accredited laboratory. The relevance of the experiment to everyday clinical practice must be demonstrated before starting the study. Thus, financial and ethical limitations are substantial obstacles to conducting in vivo animal studies.

Cyanoacrylate is emerging as an effective agent for permanent embolization, with a low rate of recanalization $[10,36,48]$. Many studies have established that cyanoacrylate glues have a broad spectrum of indications, ranging from skin-wound closure to the treatment of varicose veins $[49,50]$. The low viscosity of cyanoacrylate that allows for injection through a microcatheter is among the main features of considerable interest for endovascular applications [17]. Furthermore, the low viscosity allows the embolization of small distal arteries beyond the reach of the microcatheter tip. Moreover, the rapid polymerization of cyanoacrylate results in a smaller radiation dose to the patient when angiographic guidance is used compared to the use of particulate or solid embolization devices, such as plugs or coils.

The effects of cyanoacrylate glues on body tissues have been extensively studied. The deposition of cyanoacrylate within a vessel results in an acute inflammatory reaction in the wall and surrounding tissues. This progresses to a chronic and granulomatous process after approximately one month, with foreign body giant cells and fibrosis. Several studies from this review provided interesting histopathologic considerations that are listed in Table 4.

The main challenge in using cyanoacrylate results from the fast polymerization, which is linked to the multiple reactions involved, including initiation and propagation phases. The low viscosity may increase the risk of reflux with non-target embolization. Finally, cyanoacrylate is radiolucent. In vitro and in vivo studies have been performed to modulate polymerization, for instance, by adding glacial acetic acid [39,43,51], to induce radio-opacity by adding tantalum powder or a contrast agent [26,52], or to decrease vessel adhesivity by adding absolute ethanol [53]. In vivo assessments can help to understand the mechanisms underlying cyanoacrylate polymerization. They are also performed to characterize new liquid embolic agents, such as precipitating hydrophobic injectable liquid (PHIL ${ }^{\circledR}$, Culpan Medical, Victoria, Australia) or ethylene-vinyl alcohol copolymer (EVOH and tantalum, Squid $^{\circledR}$, Emboflu, Gland, Switzerland) [54].

We focused on studies of non-modified arteries, which are more reliable for characterizing polymerization and for designing models of ischemia. Recent studies chiefly used rabbits and swine for both ethical and financial reasons. Swine have interesting resemblances to humans in terms of vessel diameter, hemodynamics, and coagulation [55]. The main drawbacks are the need for dedicated instruments to perform the procedure and the fairly high cost of these large animals. Rabbits are available in most preclinical laboratories and exhibit blood-clotting properties similar to those of humans, although other characteristics show greater differences compared to swine. Rabbit models are less costly and seem to allow medium- to long-term follow-up [43,56]. Canine models are intermediate between swine and rabbits regarding vessel diameter, coagulation properties, and cost. However, the use of dogs has declined over time, probably due to changes in 
basic science practices. It is worth noting that animal models of non-modified arteries have also been used to test new tools, such as new types of microcatheters [23].

The cyanoacrylate glue most widely used today for endovascular interventions is Histoacryl ${ }^{\circledR}$, i.e., NBCA, with Lipiodol as the radio-opaque agent. This probably explains why most of the recent preclinical studies were completed with Histoacryl ${ }^{\circledR}$. The two countries with the largest number of publications on Histoacry $1^{\circledR}$ identified by our search are the USA and Japan, where this product has been widely available for many years. Bucrylate ${ }^{\circledR}$, or isobutyl 2-cyanoacrylate, was used more often in the 1990s, before studies showed that Histoacry $1^{\circledR}$ (NBCA) had a better safety profile, with notably less inflammation and greater tensile strength $[22,57,58]$. Glubran ${ }^{\circledR} 2$, composed of NBCA mixed with the monomer metacryloxysulfolane, was the first cyanoacrylate to receive the EC mark for endovascular use. Although Glubran ${ }^{\circledR} 2$ is commonly used in Europe for endovascular interventions, it was used in a single animal study identified by our review, with promising results [36].

Table 4. Main histopathologic findings from studies of animal models [3-6,8,13-15,17,27-29,32-36,39-41,45,46,57,59].

\begin{tabular}{lcc}
\hline Histopathologic & $\begin{array}{c}\text { Minimal Delay between } \\
\text { Findings }\end{array}$ & $\begin{array}{c}\text { Animal } \\
\text { Embolization and Description (Days) }\end{array}$ \\
\hline Sponge-like matrix with entrapped erythrocytes in its interstices & 1 & Swine, dog, rabbit \\
Desquamation of adjacent to the endothelial cells & 1 & Swine, dog \\
Infiltration of neutrophils into the adventitial layer & 1 & Dog \\
Infiltration of neutrophils into the intermediate layer & 2 & Swine, rat \\
Hyperplasia of adjacent elastic fibrils & 7 & Dog \\
Foreign body giant cells adjacent to the polymer & 7 & Swine, dog, rabbit, rat \\
Tissue necrosis & 7 & Swine, dog, rabbit, rat \\
Infarcted region calcification & 21 & Rabbit \\
\hline
\end{tabular}

The tools needed for endovascular interventions using cyanoacrylates vary according to the model used. For instance, narrower introducers are needed for rats and rabbits than for dogs, swine, and primates. Furthermore, the microcatheter, particularly the external diameter of the distal tip, must be appropriate not only for the animal species but also for the embolization site. Our review showed that the renal arteries were most often used in animal studies of cyanoacrylates. Obvious technical reasons explain this preference. Furthermore, the terminal vascularization of the kidneys allows the target embolization of a theoretically restricted area devoid of anastomoses, with better tolerance of the resulting ischemia compared to other organs. These characteristics allow for the monitoring of the vascular reaction over time, which typically consists of acute local inflammation followed by a foreign-body giant-cell reaction and fibrosis $[26,59]$.

\section{Conclusions}

We aimed to provide an exhaustive review of the preclinical animal experiments that used cyanoacrylates for endovascular interventions on non-modified arteries. We assessed the study designs, models, and endovascular procedures performed. Such studies are scarce compared to studies of embolic agents in general, and most of them used Histoacryl ${ }^{\circledR}$ or Bucrylate ${ }^{\circledR}$. Canine, rabbit, and swine models predominated, and the renal arteries were by far the most common embolization site.

Additional work is needed to better understand the mechanism of action of liquid cyanoacrylate glues that are used for endovascular interventions.

Author Contributions: Conceptualization, K.G. and R.L.; Methodology, K.G., P.-O.C. and R.L.; Software, K.G. and O.C.; Validation, O.C. and R.L.; Formal analysis, A.-V.S.; Investigation, K.G. and P.-O.C.; Resources, O.C.; Data curation, K.G.; Writing—original draft preparation, K.G., P.-O.C., O.C., A.-V.S. and R.L.; Writing-review and editing, K.G., P.-O.C., O.C., A.-V.S. and R.L.; Visualization, R.L.; Supervision, R.L.; Project administration, K.G.; Funding acquisition, O.C. All authors have read and agreed to the published version of the manuscript. 
Funding: This research was funded solely by institutional and departmental resources: no external funding was used.

Institutional Review Board Statement: Ethical review and approval were waived for this study, as it consisted in the retrospective assessment of experimental data for a review article.

Informed Consent Statement: Not applicable since this study did not involve humans.

Data Availability Statement: All the study data are reported in this article.

Conflicts of Interest: The authors declare no conflict of interest.

\section{References}

1. Li, Y.J.; Barthes-Biesel, D.; Salsac, A.V. Polymerization kinetics of n-butyl cyanoacrylate glues used for vascular embolization. J. Mech. Behav. Biomed. Mater. 2017, 69, 307-317. [CrossRef] [PubMed]

2. Bouzeghrane, F.; Naggara, O.; Kallmes, D.F.; Berenstein, A.; Raymond, J. In vivo experimental intracranial aneurysm models: A systematic review. AJNR Am. J. Neuroradiol. 2010, 31, 418-423. [CrossRef] [PubMed]

3. Murayama, Y.; Vinuela, F.; Ulhoa, A.; Akiba, Y.; Duckwiler, G.; Gobin, Y.; Vinters, H.V.; Greff, R.J. Nonadhesive liquid embolic agent for cerebral arteriovenous malformations: Preliminary histopathological studies in swine rete mirabile. Neurosurgery 1998, 43, 1164-1172. [CrossRef] [PubMed]

4. Greim-Kuczewski, K.; Berenstein, A.; Kis, S.; Hauser, A.; Killer-Oberpfalzer, M. Surgical technique for venous patch aneurysms with no neck in a rabbit model. J. Neurointervent. Surg. 2018, 10, 118. [CrossRef]

5. Brennecka, C.R.; Preul, M.C.; Bichard, W.D.; Vernon, B.L. In vivo experimental aneurysm embolization in a swine model with a liquid-to-solid gelling polymer system: Initial biocompatibility and delivery strategy analysis. World Neurosurg. 2012, 78, 469-480. [CrossRef] [PubMed]

6. Marbacher, S.; Erhardt, S.; Schläppi, J.A.; Coluccia, D.; Remonda, L.; Fandino, J.; Sherif, C. Complex bilobular, bisac cular, and broad-neck microsurgical aneurysm formation in the rabbit bifurcation model for the study of upcoming endovascular techniques. AJNR Am. J. Neuroradiol. 2011, 32, 772-777. [CrossRef] [PubMed]

7. Nakai, M.; Ikoma, A.; Loffroy, R.; Midulla, M.; Kamisako, A.; Higashino, N.; Fukuda, K.; Sonomura, T. Type II endoleak model creation and intraoperative aneurysmal sac embolization with n-butyl cyanoacrylate-lipiodol-ethanol mixture (NLE) in swine. Quant. Imaging Med. Surg. 2018, 8, 894-901. [CrossRef]

8. Zanetti, P.H.; Sherman, F.E. Experimental evaluation of a tissue adhesive as an agent for the treatment of aneurysms and arteriovenous anomalies. J. Neurosurg. 1972, 36, 72-79. [CrossRef] [PubMed]

9. Abdulmalak, G.; Chevallier, O.; Falvo, N.; Di Marco, L.; Bertaut, A.; Moulin, B.; Abu-Khalil, C.; Gehin, S.; Charles, P.E.; Latournerie, M.; et al. Safety and efficacy of transcatheter embolization with Glubran ${ }^{\circledR} 2$ cyanoacrylate glue for acute arterial bleeding: A single-center experience with 104 patients. Abdom. Radiol. 2018, 43, 723-733. [CrossRef]

10. Loffroy, R.; Comby, P.O.; Guillen, K.; Salsac, A.V. N-butyl cyanoacrylate-Lipiodol mixture for endovascular purpose: Polymerization kinetics differences between in vitro and in vivo experiments. Cardiovasc. Interv. Radiol. 2020, 43, 1409-1410. [CrossRef]

11. Moher, D.; Liberati, A.; Tetzlaff, J.; Altman, D.G. The PRISMA Group. Preferred Reporting Items for Systematic Reviews and Meta-Analyses: The PRISMA Statement. PLoS Med. 2009, 6, e1000097. [CrossRef] [PubMed]

12. Tricco, A.C.; Lillie, E.; Zarin, W.; O’Brien, K.K.; Colquhoun, H.; Levac, D.; Moher, D.; Peters, M.D.J.; Horsley, T.; Weeks, L.; et al. PRISMA Extension for Scoping Reviews (PRISMA-ScR): Checklist and Explanation. Ann. Intern. Med. 2018, 169, 467-473. [CrossRef] [PubMed]

13. Guo, J.; Liao, J.; Preston, J.; Batjer, H. A canine model of acute hindbrain ischemia and reperfusion. Neurosurgery 1995, 36, 986-992. [CrossRef] [PubMed]

14. Matos, G.F.; Hammadeh, R.; Francois, C.; McCarthy, R.; Leya, F. Controlled myocardial infarction induced by intracoronary injection of n-butyl cyanoacrylate in dogs: A feasibility study. Catheter. Cardiovasc. Interv. 2005, 66, 244-253. [CrossRef]

15. Jae, H.J.; Chung, J.W.; Kim, H.C.; So, Y.H.; Lim, H.G.; Lee, W.; Kim, B.K.; Park, J.H. Experimental study on acute ischemic small bowel changes induced by superselective embolization of superior mesenteric artery branches with N-butyl cyanoacrylate. J. Vasc. Interv. Radiol. 2008, 19, 755-763. [CrossRef]

16. Dotter, C.T.; Goldman, M.L.; Rösch, J. Instant selective arterial occlusion with isobutyl 2-cyanoacrylate. Radiology 1975, $114,227$. [CrossRef]

17. Takasawa, C.; Seiji, K.; Matsunaga, K.; Matsuhashi, T.; Ohta, M.; Shida, S.; Takase, K.; Takahashi, S. Properties of N-butyl cyanoacrylate-iodized oil mixtures for arterial embolization: In vitro and in vivo experiments. J. Vasc. Interv. Radiol. 2012, 23, 1215-1221. [CrossRef]

18. Cromwell, L.D.; Freeny, P.C.; Kerber, C.W.; Kunz, L.L.; Harris, A.B.; Shaw, C.M. Histologic analysis of tissue response to bucrylate-pantopaque mixture. AJR Am. J. Roentgenol. 1986, 147, 627-631. [CrossRef] [PubMed]

19. Spiegel, S.M.; Vinuela, F.; Goldwasser, J.M.; Fox, A.J.; Pelz, D.M. Adjusting the polymerization time of isobutyl-2 cyanoacrylate. AJNR Am. J. Neuroradiol. 1986, 7, 109-112.

20. Sadato, A.; Wakhloo, A.K.; Hopkins, L.N. Effects of a mixture of a low concentration of N-butylcyanoacrylate and ethiodol on tissue reactions and the permanence of arterial occlusion after embolization. Neurosurgery 2000, 47, 1197-1203. [CrossRef] 
21. Szmigielski, W.; Klamut, M.; Wolski, T.; Studnicki, W.; Rubaj, B. Urogranoic acid as a radiopaque additive to the cyanoacrylic adhesive in transcatheter obliteration of renal arteries. Investig. Radiol. 1981, 16, 65-70. [CrossRef]

22. Oowaki, H.; Matsuda, S.; Sakai, N.; Ohta, T.; Iwata, H.; Sadato, A.; Taki, W.; Hashimoto, N.; Ikada, Y. Non-adhesive cyanoacrylate as an embolic material for endovascular neurosurgery. Biomaterials 2000, 21, 1039-1046. [CrossRef]

23. Debrun, G.M.; Vinuela, F.V.; Fox, A.J.; Kan, S. Two different calibrated-leak balloons: Experimental work and application in humans. AJNR Am. J. Neuroradiol. 1982, 3, 407-414.

24. Khangure, M.S.; Ap Simon, H.T.; Chakera, T.M.; Hartley, D.E. A catheter system for the safe and efficient delivery of tissue glues (bucrylate) for visceral embolization. Br. J. Radiol. 1981, 54, 671-673. [CrossRef]

25. ApSimon, H.T.; Hartley, D.E.; Maddren, L.; Harper, C. Embolization of small vessels with a double-lumen microballoon catheter. Part II: Laboratory, animal, and histological studies. Work in progress. Radiology 1984, 151, 59-64. [CrossRef]

26. Stoesslein, F.; Ditscherlein, G.; Romaniuk, P.A. Experimental studies on new liquid embolization mixtures (histoacryl-lipiodol, histoacryl-panthopaque). Cardiovasc. Intervent. Radiol. 1982, 5, 264-267. [CrossRef] [PubMed]

27. Izaaryene, J.; Saeed Kilani, M.; Rolland, P.H.; Gaubert, J.Y.; Jacquier, A.; Bartoli, J.M.; Vidal, V. Preclinical study on an animal model of a new non-adhesive cyanoacrylate (Purefill ${ }^{\circledR}$ ) for arterial embolization. Diagn. Interv. Imaging 2016, 97, 1109-1116. [CrossRef]

28. Tanaka, F.; Kawai, N.; Sato, M.; Minamiguchi, H.; Nakai, M.; Nakata, K.; Sanda, H.; Sonomura, T.; Matuzaki, I.; Murata, S. Effect of transcatheter arterial embolization with a mixture of n-butyl cyanoacrylate, lipiodol, and ethanol on the vascular wall: Macroscopic and microscopic studies. Jpn. J. Radiol. 2015, 33, 404-409. [CrossRef]

29. Hamaguchi, S.; Lohman, B.D.; Ogawa, Y.; Arai, Y.; Hashimoto, K.; Matsumoto, J.; Nakajima, Y. Preliminary findings of arterial embolization with balloon-occluded and flow-dependent histoacryl glue embolization in a swine model. Jpn. J. Radiol. 2015, 33, 344-351. [CrossRef]

30. Bruhn, R.S.; Distelmaier, M.S.; Hellmann-Sokolis, M.; Naami, A.; Kuhl, C.K.; Hohl, C. Early detection of acute mesenteric ischemia using diffusion-weighted 3.0-T magnetic resonance imaging in a porcine model. Investig. Radiol. 2013, 48, 231-237. [CrossRef]

31. Sonomura, T.; Kawai, N.; Ikoma, A.; Minamiguchi, H.; Ozaki, T.; Kishi, K.; Sanda, H.; Nakata, K.; Nakai, M.; Muragaki, Y.; et al. Uterine damage in swine following uterine artery embolization: Comparison among gelatin sponge particles and two concentrations of N-butyl cyanoacrylate. Jpn. J. Radiol. 2013, 31, 685-692. [CrossRef]

32. Okada, T.; Yamaguchi, M.; Takahashi, T.; Izaki, K.; Uotani, K.; Sakamoto, N.; Sugimura, K.; Sugimoto, K. Is embolization of the pancreas safe? Pancreatic histological changes after selective transcatheter arterial embolization with N-butyl cyanoacrylate in a swine model. Cardiovasc. Intervent. Radiol. 2012, 35, 161-167. [CrossRef]

33. Tanaka, T.; Kawai, N.; Sato, M.; Ikoma, A.; Nakata, K.; Sanda, H.; Minamiguchi, H.; Nakai, M.; Sonomura, T.; Mori, I. Safety of bronchial arterial embolization with n-butyl cyanoacrylate in a swine model. World J. Radiol. 2012, 4, 455-461. [CrossRef]

34. Ikoma, A.; Kawai, N.; Sato, M.; Sonomura, T.; Minamiguchi, H.; Nakai, M.; Takasaka, I.; Nakata, K.; Sahara, S.; Sawa, N.; et al. Ischemic effects of transcatheter arterial embolization with N-butyl cyanoacrylate-lipiodol on the colon in a swine model. Cardiovasc. Intervent. Radiol. 2010, 33, 1009-1015. [CrossRef]

35. Yonemitsu, T.; Kawai, N.; Sato, M.; Sonomura, T.; Takasaka, I.; Nakai, M.; Minamiguchi, H.; Sahara, S.; Iwasaki, Y.; Naka, T.; et al. Comparison of hemostatic durability between N-butyl cyanoacrylate and gelatin sponge particles in transcatheter arterial embolization for acute arterial hemorrhage in a coagulopathic condition in a swine model. Cardiovasc. Intervent. Radiol. 2010, 33, 1192-1197. [CrossRef]

36. Levrier, O.; Mekkaoui, C.; Rolland, P.H.; Murphy, K.; Cabrol, P.; Moulin, G.; Bartoli, J.M.; Raybaud, C. Efficacy and low vascular toxicity of embolization with radical versus anionic polymerization of n-butyl-2-cyanoacrylate (NBCA). An experimental study in the swine. J. Neuroradiol. 2003, 30, 95-102.

37. Klein, H.M.; Klosterhalfen, B.; Kinzel, S.; Jansen, A.; Seggewiss, C.; Weghaus, P.; Kamp, M.; Töns, C.; Günther, R.W. CT and MRI of experimentally induced mesenteric ischemia in a porcine model. J. Comput. Assist. Tomogr. 1996, 20, 254-261. [CrossRef]

38. Widlus, D.M.; Lammert, G.K.; Brant, A.; Tsue, T.; Samphilipo, M.A., Jr.; Magee, C.; Starr, F.L.; Anderson, J.H.; White, R.I., Jr. In vivo evaluation of iophendylate-cyanoacrylate mixtures. Radiology 1992, 185, 269-273. [CrossRef]

39. Brothers, M.F.; Kaufmann, J.C.; Fox, A.J.; Deveikis, J.P. N-butyl 2-cyanoacrylate-substitute for IBCA in interventional neuroradiology: Histopathologic and polymerization time studies. AJNR Am. J. Neuroradiol. 1989, 10, 777-786. [PubMed]

40. Miller, F.J.J.; Rankin, R.S.; Gliedman, J.B. Experimental internal iliac artery embolization: Evaluation of low viscosity silicone rubber, isobutyl 2-cyanoacrylate, and carbon microspheres. Radiology 1978, 129, 51-58. [CrossRef] [PubMed]

41. Wang, Y.M.; Cheng, L.F.; Li, N. Histopathological study of vascular changes after intra-arterial and intravenous injection of N-butyl-2-cyanoacrylate. Chin. J. Dig. Dis 2006, 7, 175-179. [CrossRef]

42. Shi, Z.; Huang, Z.; Zhang, Y.; Qi, T.; Chu, M.; Bao, D. Experimental study of Eudragit mixture as a new nonadhesive liquid embolic material. Chin. Med. J. 2002, 115, 555-558.

43. Gounis, M.J.; Lieber, B.B.; Wakhloo, A.K.; Siekmann, R.; Hopkins, L.N. Effect of glacial acetic acid and ethiodized oil concentration on embolization with N-butyl 2-cyanoacrylate: An in vivo investigation. AJNR Am. J. Neuroradiol. 2002, 23, 938-944.

44. Salomonowitz, E.; Gottlob, R.; Castaneda-Zuniga, W.; Amplatz, K. Work in progress: Transcatheter embolization with cyanoacrylate and nitrocellulose. Radiology 1983, 149, 445-458. [CrossRef]

45. Günther, R.; Schubert, U.; Bohl, J.; Georgi, M.; Marberger, M. Transcatheter embolization of the kidney with butyl-2-cyanoacrylate: Experimental and clinical results. Cardiovasc. Radiol. 1978, 1, 101-108. [CrossRef] 
46. Raymond, J.; Berthelet, F.; Desfaits, A.C.; Salazkin, I.; Roy, D. Cyanoacrylate embolization of experimental aneurysms. AJNR Am. J. Neuroradiol. 2002, 23, 129-138.

47. Donnan, G.A.; Davis, S.M. Stroke drug development: Usually, but not always, animal models. Stroke 2005, 36, 2326. [CrossRef]

48. Shuster, A.; Gunnarsson, T.; Klurfan, P.; Larrazabal, R. N-butyl cyanoacrylate proved beneficial to avoid a nontarget embolization of the ophthalmic artery in endovascular management of epistaxis. A neurointerventional report and literature review. Interv. Neuroradiol. 2011, 17, 17-21. [CrossRef]

49. Duffy, C.; Zetterlund, P.B.; Aldabbagh, F. Radical polymerization of alkyl 2-cyanoacrylates. Molecules 2018, 23, 465. [CrossRef]

50. Almeida, J.I.; Javier, J.J.; Mackay, E.G.; Bautista, C.; Cher, D.J.; Proebstle, T.M. Thirty-sixth-month follow-up of first-in-human use of cyanoacrylate adhesive for treatment of saphenous vein incompetence. J. Vasc. Surg. Venous Lymphat. Disord. 2017, 5, 658-666. [CrossRef]

51. Li, Y.J.; Barthes-Biesel, D.; Salsac, A.V. Polymerization kinetics of a mixture of Lipiodol and Glubran 2 cyanoacrylate glue upon contact with a proteinaceous solution. J. Mech. Behav. Biomed. Mater. 2017, 74, 84-92. [CrossRef] [PubMed]

52. Stanley, A.J.; Smith, L.A.; Morris, A.J. Use of hemostatic powder (Hemospray) in the management of refractory gastric variceal hemorrhage. Endoscopy 2013, 45, E86-E87. [CrossRef] [PubMed]

53. Kawai, N.; Sato, M.; Minamiguchi, H.; Ikoma, A.; Sanda, H.; Nakata, K.; Tanaka, F.; Nakai, M.; Sonomura, T. Basic study of a mixture of N-butyl cyanoacrylate, ethanol, and lipiodol as a new embolic material. J. Vasc. Interv. Radiol. 2012, 23, 1516-1521. [CrossRef] [PubMed]

54. Vollherbst, D.F.; Otto, R.; Hantz, M.; Ulfert, C.; Kauczor, H.U.; Bendszus, M.; Sommer, C.M.; Möhlenbruch, M.A. Investigation of a new version of the liquid embolic agent PHIL with extra-low-viscosity in an endovascular embolization model. AJNR Am. J. Neuroradiol. 2018, 39, 1696-1702. [CrossRef] [PubMed]

55. Massoud, T.; Ji, C.; Vinuela, F.; Turjman, F.; Guglielmi, G.; Duckwiler, G.; Gobin, Y.P. Laboratory simulations and training in endovascular embolotherapy with a swine arteriovenous malformation model. AJNR Am. J. Neuroradiol. 1996, 17, 271-279. [PubMed]

56. Grunwald, I.Q.; Romeike, B.; Eymann, R.; Roth, C.; Struffert, T.; Reith, W. An experimental aneurysm model: A training model for neurointerventionalists. Interv. Neuroradiol. 2006, 12, 17-24. [CrossRef]

57. Carmignani, G.; Belgrano, E.; Puppo, P. Evaluation of different types of emboli in transcatheter embolization of rat kidney. Urol Res. 1977, 5, 127-132. [CrossRef] [PubMed]

58. Carmignani, G.; Belgrano, E.; Puppo, P.; Giuliani, L. Cyanoacrylates in transcatheter renal embolization. Acta Radiol. Diagn. 1978, 19, 49-56. [CrossRef] [PubMed]

59. Leonardi, M.; Cenni, P.; Simonetti, L.; Bozzao, A.; Romano, A.; Bonamini, M.; Fantozzi, L.M.; Fini, G. Glubran $2^{\circledR}$ : A new acrylic glue for neuroradiological endovascular use: A complementary histological study. Interv. Neuroradiol. 2003, 9, 249-254. [CrossRef] 